\title{
The Influence of Facility and Service Quality towards Customer Satisfaction and Its Impact on Customer Loyalty in Borobudur Hotel in Jakarta
}

\author{
Rianto Nurcahyo ${ }^{1}$; Annisa Fitriyani²; Irma Nur Hudda ${ }^{3}$ \\ 1,2,3 International Business Management, School of Business Management, Bina Nusantara University \\ Jln. Jalur Sutera Barat Kav. 21 Alam Sutera, Tangerang 15143, Indonesia \\ 'rnurtjahjo@binus.edu; ${ }^{2}$ annfitriyani@gmail.com; ${ }^{3}$ irmahudda@gmail.com
}

Received: $11^{\text {th }}$ October 2016/ Revised: $31^{\text {st }}$ January 2017/ Accepted: $3^{\text {rd }}$ March 2017

How to Cite: Nurcahyo, R., Fitriyani, A., \& Hudda, I. N. (2017). The Influence of Facility

and Service Quality towards Customer Satisfaction and Its Impact on Customer

Loyalty in Borobudur Hotel in Jakarta. Binus Business Review, 8(1), 23-29.

http://dx.doi.org/10.21512/bbr.v8i1.1790

\begin{abstract}
Hotel developments currently grow very rapidly. The emergence of new hotels increases the competition in the hospitality industry. This research aimed to determine the influence of the facilities, the quality of service to customer satisfaction and its impact on customer loyalty in Borobudur Hotel in Jakarta. Data collection were done by distributing questionnaires directly to 360 customers in Borobudur Hotel, Jakarta. The analysis technique used path analysis. The results of this research indicate that the variables of facilities, service quality, and customer satisfaction significantly affect customer loyalty variables simultaneously or partially. In addition, facilities and quality of service variable have a significant effect on customer satisfaction variables.
\end{abstract}

Keywords: facility, service quality, customer satisfaction, customer loyalty

\section{INTRODUCTION}

In this globalization era, the competition in business is increasingly tight. Globalization has caused various industries to develop rapidly, whether it is a product industry or service industry. Service can be defined as economic activities offered by one party to another, about desired results to recipients, objects or other assets for which purchasers have a responsibility (Alaska \& Supain, 2014). This makes each company compete with the competitors by implementing the right marketing strategy to persist in the business they organize. In a service industry such as hospitality, some countries have built their hotels vigorously in their area (Alexander, 2015). In this proposed model of service quality measurement, gap analysis is used to find the difference between customers' expected service performance and actual service performance. It can be considered that globalization has given indirect impact to the rapid growth of hotel supplies in some countries in Asia. Quoted from an article in kompas. com regarding booming hotel in Indonesia in 20152018 , it is noted that in Indonesia, the government has planned to develop more than 560 new tour destinations in 19 provinces in Indonesia, which was well received by business people and hospitality industry. It caused the construction of hotels more intense in 2015-2018 in Jakarta and Bali as a reference region (Alexander, 2015).

Furthermore, the high growth of hotel supplies in Asia can be associated with the tourism condition in the country. For many developing countries, travel and tourism serve as the primary export industry. The vast majority of hotel supply growth in recent years can be attributed to the development of budget and economy class hotels. (Vadehra, 2015). Figure 1 shows the growth in hotel supply in Indonesia. 


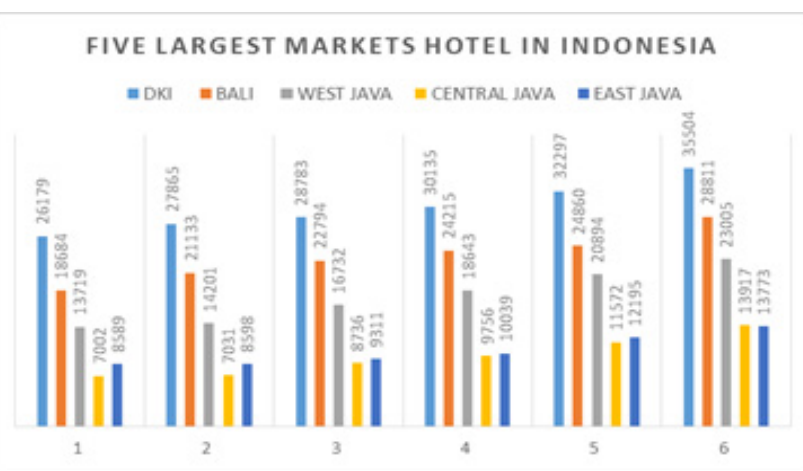

Figure 1 The Five Largest Markets of Hotel In Indonesia

(Source: Badan Pusat Statistik)

However, regarding overall trade dollars, that in industrialized countries, some of the largest beneficiaries are inbound international travels (Baker, 2014). Tourism is one of the sectors that continue to be developed by the government. This tourism sector can bring in foreigner tourists and domestic tourists that will give an advantage to the foreign exchange income (Sofyan et al., 2013). Besides, tourism on its progress always relates to hospitality industries, where the tourists need a place to stay in their tour (Hana, 2014). Peric (2005) pointed out that globalization has opened a whole new world of development opportunities. 715 million of people traveled abroad in 2002 , so by 2020 , this number is expected to increase to 1,6 billion. The tourism turnover is $\$ 3.500$ billion, and $10 \%$ of global trade. Hence, tourism has become a big business which is run by great trusts.

Then, the growth of hotel supplies in each country is certainly based on the number of visiting tourists. To fulfill the needs of the incoming tourists, hotels built also vary, which each hotel competes to attract their guests. There are around 228 new hotels in Jakarta that were built during 2015 which also raised the competition to Borobudur Hotel as a five-star hotel that was established since 1969. Regarding that fact, Borobudur Hotel should pay attention to their facility and service quality to increase customers' satisfaction and loyalty, so Borobudur Hotel can still compete in the hospitality industry that keeps growing. Borobudur Hotel itself is a five-star hotel located in the center of Jakarta, Central Jakarta. With a very strategic location, right in the middle of the town, Borobudur Hotel has become an option for the guests who want to have vacation or business trip. Despite the strategic location, it is not guaranteed that they will get many customers. To survive in the business competition, and qualify the operational, the hotel occupancy rate should be at the least $70 \%$. From the condition of tight competition, the fluctuations in occupancy rates, and the price competitions for 5-star hotels that offer the services and facilities to attract consumers, there are hotels that can survive under the conditions of exceeded supply over demand. The hotels that can survive show that they prepare, innovate and utilize their dynamic marketing capabilities to adapt to the market dynamics as well as to meet the customers' needs. The abilities required to survive the competition are ability to provide excellent service to consumers' demands by continuously learning for the hotel management and the staffs, to the service process and delivery according to the segment, to continuously improve for servicescape, to invite the consumers to participate more actively, and to be responsive to customers' needs and expectations.

In here, the research gap is by considering the customer satisfaction as the mediating variable between service quality and customer loyalty. Taylor and Baker (1994) found that satisfaction acted as a moderator between service quality and loyalty in three of the four industries studied. However, the research showed that it acted as a mediator instead of a moderator. Bou-Llusar et al., (2001) considered satisfaction as a mediating variable and moderating variable between service quality and purchase intentions. They found that satisfaction was as a mediating variable between firm perceived quality and purchase intentions.

According to Soenarno (2006), hotel facilities that could be enjoyed by customers were: (1) lobby, (2) exclusive way to shopping center, (3) pick up facility in airport, (4) outlets or stores around the hotel, (5) babysitting facility, (6) balcony, (7) meeting room, (8) business center, (9) cake shop, (10) coffee shop, (11) 24-hours doctor, (12) afternoon service, (13) quick check-in/check-out process, (14) 24-hours room services, (15) 24-hours security, (16) 24-hours coffee shop, (17) laundry, (18) massage center, (19) mini bar, (20) restaurant, (21) pool, (22) sports field and (23) travel agent. Soenarno (2006) also said that few facilities provided in hotel bedroom were (1) bedroom, (2) television with video player, (3) radio, (4) clock, (5) safe deposit box, (6) internet access, (7) dresser, (8) coffee table, (9) dinner table, (10) telephone, (11) sandals, (12) wardrobe, (13) refrigerator, (14) couch and table, and (15) emergency lamp. Moreover, the expected service quality refers to the expectations of customers related to service and the features which customers want to have to be satisfied (Bucak, 2014). Meanwhile, customer perception towards a service can also be influenced by the atmosphere created by the facility from the relevant exterior and interior. Santoso (2013) pointed out that service quality provided a perfect service to fulfill customers' hopes and needs. By various definitions stated, it can be said that service quality is a performance given to customers to fulfill their needs and expectations.

According to Sakhaei et al. (2014), customer satisfaction was a comparison between services or results accepted by the consumer with a hope that the services or results accepted met their expectations or more. However, there is a general agreement that customer satisfaction is a final product of the postconsumption of a product or service. The customer service is different from customer loyalty. Customer loyalty can be achieved in some cases by offering a qualified product with a firm guarantee or through 
free offers, coupons, low-interest rates on financing, high-value trade-ins, extended warranties, rebates, and other rewards and incentive programs. The ultimate goal of these is to develop happy customers who will return to purchase again and persuade others to use that company's products or services (Poku et al., 2013). Loyalty is built and developed within the framework of an enduring relationship that the customer builds with the company following the different consumption experiences (Hikkerova, 2014). Therefore, trust and mutual commitment become determining factors for an enduring relationship and building customer loyalty. It can be considered that customers are satisfied when there is a positive feeling that emerges from expected evaluation process, including the decision to buy, and the needs and wants associated with the buying.

Moreover, according to Holjevac et al. (2009), satisfaction could be determined subjectively (customer needs and emotions) and objectively (product and service features). Applying to the hospitality industry, there have been numerous researches examining attributes that travelers may find important regarding customers' satisfaction. Satisfaction is about how customers' needs and demands meet while loyalty is about how customers repeat purchasing product or services. It is possible that a customer who is satisfied with the service may be loyal towards it. Meanwhile, it is impossible to happen for the customer without satisfaction loyal towards the organization (Munir \& Lodhi, 2015).

From the collected data, it seems interesting to conduct research to find out whether Borobudur Hotel in Jakarta can keep competing with other similar hotels. This is conducted by doing research about customer satisfaction and customer loyalty through this research entitled influence of facilities and service quality towards customer satisfaction and its impact on customer loyalty of Borobudur Hotel to see how are the impacts of those variables towards customer satisfaction and loyalty. Moreover, it is difficult to obtain the data from the company needed for the continuity of this research. It is because the data is kept secret by the company so that researchers cannot put the data in the appendix of this research. The other limitations faced by researchers in conducting this research is the difficulty in getting respondents. The researchers have to return to the Borobudur Hotel in Jakarta for several times to get the required number of respondents.

There are several research problems in this research. There are (1) how facility (X1) can influence customer satisfaction (Y) in Borobudur Hotel in Jakarta; (2) how service quality (X2) can influence customer satisfaction (Y) in Borobudur Hotel in Jakarta; (3) how facility (X1) can influence customer loyalty (Z) in Borobudur Hotel in Jakarta; (4) how service quality (X2) can influence customer loyalty (Z) in Borobudur Hotel in Jakarta; (5) how customer satisfaction (Y) can influence customer loyalty $(\mathrm{Z})$ in Borobudur Hotel in Jakarta; (6) how facility (X1) and service quality (X2) influence customer satisfaction (Y); (7) how facility (X1) and service quality (X2) influence customer satisfaction (Y) and customer loyalty $(Z)$.

In addition, the research purposes are as follows: (1) to know the influence between facility and customer satisfaction in Borobudur Hotel in Jakarta; (2) to find out the influence of service quality and customer satisfaction in Borobudur Hotel in Jakarta; (3) to analyze the influence between facility and customer loyalty in Borobudur Hotel in Jakarta; (4) to see the influence of service quality towards customer loyalty in Borobudur Hotel in Jakarta; (5) to find out the influence of customer satisfaction towards customer loyalty in Borobudur Hotel in Jakarta; (6) to see the indirect influence of facility towards loyalty through customer satisfaction in Borobudur Hotel in Jakarta; (7) to know the indirect influence of service quality towards customer loyalty and customer satisfaction in Borobudur Hotel in Jakarta.

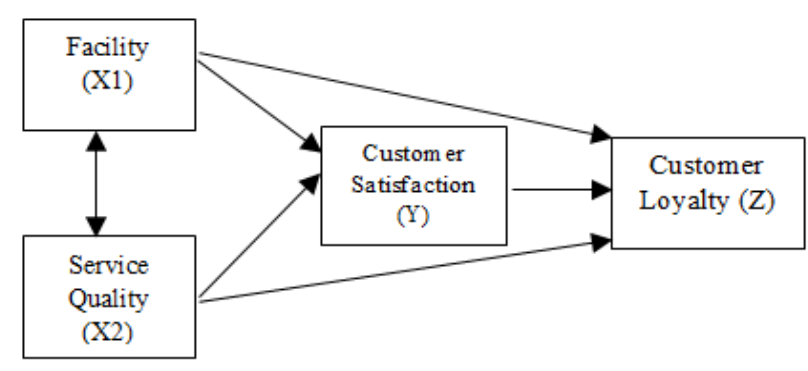

Figure 2 Research Framework

Figure 2 shows the framework for this research. Based on the research problems and objectives, the hypotheses that can be drawn are as follows:

- $\mathrm{H}_{\mathrm{o}} 1=$ There is no influence of facilities (X1) on customer satisfaction (Y)

$\cdot \mathrm{H}_{\mathrm{a}} 1=$ There is the influence of the facility (X1) on customer satisfaction (Y)

- $\mathrm{H}_{\mathrm{o}} 2=$ There is no impact on service quality (X2) on customer satisfaction (Y)

$\cdot \mathrm{H}_{\mathrm{a}} 2=$ There is influence service quality (X2) on customer satisfaction (Y)

- $\mathrm{H}_{0} 3=$ There is no influence on customer satisfaction $(\mathrm{Y})$

- $\mathrm{H}_{\mathrm{a}} 3=$ There is an effect of customer satisfaction $(\mathrm{Y})$ on customer loyalty $(\mathrm{Z})$

$\cdot \mathrm{H}_{\mathrm{o}} 4=$ There is no influence of facility (X1) on customer loyalty $(\mathrm{Z})$

$\cdot \mathrm{H}_{\mathrm{a}} 4=$ There is the influence of the facility (X1) on customer loyalty $(Z)$

$\cdot \mathrm{H}_{\mathrm{o}} 5=$ There is no impact on service quality (X2) on customer loyalty (Z)

- $\mathrm{H}_{\mathrm{a}} 5=$ There is influence service quality (X2) on customer loyalty $(\mathrm{Z})$ 
$\cdot \mathrm{H}_{\mathrm{o}} 6=$ There is no significant influence of the facility (X1) and service quality (X2) on customer satisfaction $(\mathrm{Y})$

- $\mathrm{H}_{\mathrm{a}} 6=$ There is a significant relationship between facilities (X1) and service quality (X2) on customer satisfaction (Y)

$\cdot \mathrm{H}_{0} 7=$ There is no significant influence of the facility (X1) and service quality (X2) on customer satisfaction $(\mathrm{Y})$ and customer loyalty $(Z)$

- $\mathrm{H}_{\mathrm{a}} 7=$ There is a significant relationship between facilities (X1) and service quality (X2) on customer satisfaction (Y) and customer loyalty $(\mathrm{Z})$

\section{METHODS}

This research is an associative research which aims to know the influence or relationship between two or more variables. This research uses cross section time dimension (Neolaka, 2014). A crosssectional study is a study that collects data only one time as said by Sekaran (2013). Therefore, the information for this research is collected from the employees done in one specific time. In this research, sampling used is non-probability sampling. Nonprobability sampling is sampling technique where each population members does not have a similar chance as a sample. This sampling technique is used if the sample representative is not important. Moreover, the sampling technique is purposive sampling, which is a determination sampling technique with exclusive consideration until it is considered appropriate to be a sample. The sample as a part of the population is classified as chosen members but is not every element in population for the research (Sekaran, 2013). If there are 1000 populations, it can be only 400 to 500 people chosen as a sample. In this research, the sample is 360 people. Then, this research has a facility (X1) and service quality (X2) as an independent variable, customer satisfaction $(\mathrm{Y})$ as intervention variable and customer loyalty $(Z)$ as a dependent variable.

For data collection, this research uses questionnaire. The questionnaire is the technique of collecting data by giving written questions which will be answered to selected respondents (Sugiyono, 2012). Meanwhile, data analysis procedure is done through research instrument test (validity and reliability test). As said by Santoso (2015), validity test aims to measure whether questions submitted is already valid or not. On the contrary, reliability test is used to test the measuring instrument. That means questions in the questionnaire are considered consistent if the measurement has repeatedly been done.

Classic Assumption tests involve normality, multicollinearity, and heteroscedasticity test. Normality test aims to know whether a residual value from a regression model has a normal distribution. If the residual value is not normally distributed, it has a problem in normality assumption. Priyatno (2014) said that normality of data was an important thing because normally distributed data was considered to represent the population. Multicollinearity test is to know whether there is a correlation between the independent variable in the regression model. If there is a correlation, there is a multicollinearity problem. A good regression model should not have a strong and significant correlation between independent variables. Heteroscedasticity test is to find out whether there are indifference in residual variant from one observation to other observation in the regression model. If the residual variant is constant from one observation to other observation, it is called homoscedasticity. If it is different, it is called heteroscedasticity. According to Ghozali (2013), the outlier is a data or case that had a unique characteristic, and looks far different from the other observations and showed a very good value for the single variable or mixed variable. According to Sugiyono (2012), path analysis is a development from regression analysis so that regression analysis can be said as an exclusive form of path analysis. Path analysis is used to test the relationship between cause and effect variables. Therefore, the independent variable is called exogenous variable, and the dependent variable is endogen variable which can be found in the correlation between variables model.

Next, the findings are drawn from the analysis with managers and guests in Borobudur Hotel. The analysis synthesizes the comments of the hotel managers and guests based on the conceptual framework consisting of four dimensions or themes. They are facilities and service quality, customer satisfaction and customer loyalty. These dimensions can give the careful analysis of the perspectives of the participating general managers and guests, even though they are closely related and also overlap in practical terms.

\section{RESULTS AND DISCUSSIONS}

Table 1 Sub-Structure 1 of Coefficient Path Result

\begin{tabular}{lccccc}
\hline $\begin{array}{c}\text { Influence of } \\
\text { Variables }\end{array}$ & $\begin{array}{c}\text { Standardized } \\
\text { Coefficients } \\
\text { (Beta) }\end{array}$ & Sig & Test Result & $\begin{array}{c}\text { Determinant } \\
\text { Coefficient }\end{array}$ & $\begin{array}{c}\text { Other } \\
\text { Variable } \\
\text { Coefficient }\end{array}$ \\
\hline X1 towards & 0,258 & 0,000 & Significant & $\begin{array}{c}0,300 \\
=\end{array}$ & 0,7 \\
Y & 0,400 & 0,000 & Significant & $30 \%$ & \\
X2 towards & & & & & \\
Y & & & & & \\
\hline
\end{tabular}

As shown in Table 1, It is found that the facilities and quality of service have the positive and significant impact on customer satisfaction in Borobudur Hotel in Jakarta. It can be seen from Table 1 that it is 0,300 with a probability value $(\mathrm{Sig})=(0,000)$. Facility $(\mathrm{X} 1)$ and service quality (X2) variables influence the customer satisfaction (Y) simultaneously and significantly. Facility (X1) and service quality (X2) affect customer 
satisfaction (Y) around 30\%. The percentage of other variables influencing customer satisfaction (Y), beyond facility (X1) and service quality (X2) is $70 \%$.

Table 2 Sub-Structure 2 of Coefficient Path Result

\begin{tabular}{lccccc}
\hline $\begin{array}{l}\text { Influence of } \\
\text { Variables }\end{array}$ & $\begin{array}{c}\text { Standardized } \\
\text { Coefficients } \\
\text { (Beta) }\end{array}$ & Sig & Test Result & $\begin{array}{c}\text { Determinant } \\
\text { Coefficient }\end{array}$ & $\begin{array}{c}\text { Other } \\
\text { Variable } \\
\text { Coefficient }\end{array}$ \\
\hline $\begin{array}{l}\text { X1 towards } \\
\mathbf{Z}\end{array}$ & 0,366 & 0,000 & Significant & 0,762 & 0,238 \\
$\mathbf{X}$ 2 towards & 0,641 & 0,000 & Significant & $76,2 \%$ & \\
$\mathbf{Z}$ & & & & & \\
$\mathbf{Y}$ towards & 0,079 & 0,013 & Significant & & \\
$\mathbf{Z}$ & & & & & \\
\hline
\end{tabular}

These findings indicate that the facility, service quality, and customer satisfaction has a positive and significant impact on customer loyalty in Borobudur Hotel in Jakarta in Table 2. It can be seen there is 0,762 with a probability value $(\mathrm{Sig})=(0,000)$. Table 2 shows that facility (X1) and service quality (X2) have a simultaneous and significant influence towards customer loyalty (Z). Facility (X1) and service quality (X2) affect customer loyalty (Z) around 76,2\%. Meanwhile, the other variables that influence customer loyalty (Z) beyond facility (X1) and service quality (X2) are $23,8 \%$.

Table 3 gives details about the influence of facility (X1) and service quality (X2) towards customer satisfaction $(\mathrm{Y})$, and the impact on customer loyalty (Z). First, facility (X1) gives 0,258 or $25,8 \%$ direct influence towards customer satisfaction (Y). Meanwhile, other $74,2 \%$ is influenced by other variables beyond facility (X1). Second, service quality (X) influence customer satisfaction (Y) 0,40 or $40 \%$. However, the other $60 \%$ is influenced by variables other than service quality (X). Third, facility (X1) affects customer loyalty (Z) around 0,366 or $36,6 \%$ directly. Moreover, facility (X1) gives 0,020 or $2 \%$ indirect influence towards customer loyalty $(Z)$. In short, direct influence is bigger than the indirect influence of facility (X1) on the customer loyalty (Z) variable. It means if facility (X1) is improved, customer loyalty $(Z)$ will also improve. Fourth, service quality (X2) has direct influence about 0,641 or $64,1 \%$ towards customer loyalty $(\mathrm{Z})$. On the contrary, there is 0,672 or $67,2 \%$ of indirect influence of service quality (X2) towards customer loyalty (Z). This result shows that indirect influence is bigger than the direct influence. It means if the service quality (X2) is improved, the customer loyalty (X2) will also improve and give an impact to customer loyalty (Z). Fifth, customer satisfaction $(\mathrm{Y})$ has 0,079 or $7,9 \%$ of direct influence on customer loyalty $(\mathrm{Z})$. On the other hand, the other $92,1 \%$ is influenced by other variables out of this research. Sixth, facility (X1) and service quality (X2) influence customer loyalty (Z) simultaneously. The amount of influence that facility (X1) and service quality (X2) have on customer loyalty $(\mathrm{Z})$ is 0,300 or $30 \%$. Unfortunately, the other $70 \%$ is influenced by other factors outside this research. Last, facility (X1), service quality (X2), and customer satisfaction (Y) influence customer loyalty (Z) simultaneously. It shows there is 0,762 or $76,2 \%$ of the influence of facility (X1), service quality (X2), and customer satisfaction (Y) towards customer loyalty $(\mathrm{Z})$ around. However, the other $23,8 \%$ is from other variables beyond the variables in this research.

Table 3 Path Analysis Summary

\begin{tabular}{|c|c|c|c|c|c|}
\hline \multirow[t]{2}{*}{ Variable } & \multirow{2}{*}{$\begin{array}{c}\text { Path } \\
\text { Analysis }\end{array}$} & \multicolumn{3}{|c|}{ Influence } & \multirow{2}{*}{$\begin{array}{l}\text { Mutual } \\
\text { Influence }\end{array}$} \\
\hline & & Direct & $\begin{array}{c}\text { Indirect } \\
\text { (Through Y } \\
\text { Variable) }\end{array}$ & Total & \\
\hline X1 towards Y & 0,258 & 0,258 & - & 0,258 & - \\
\hline X2 towards Y & 0,400 & 0,400 & - & 0,400 & - \\
\hline $\mathrm{X} 1$ towards $\mathrm{Z}$ & 0,366 & 0,366 & $\begin{array}{c}0,258 \times 0,079= \\
0,020\end{array}$ & 0,386 & - \\
\hline X2 towards Z & 0,641 & 0,641 & $\begin{array}{c}0,400 \times 0,079= \\
0,031\end{array}$ & 0,672 & - \\
\hline$Y$ towards $Z$ & 0,079 & 0,079 & - & 0,079 & - \\
\hline $\begin{array}{l}\mathrm{X} 1, \mathrm{X} 2 \\
\text { towards } \mathrm{Y}\end{array}$ & - & - & - & - & 0,300 \\
\hline $\begin{array}{l}\mathrm{X} 1, \mathrm{X} 2 \text {, and } \mathrm{Y} \\
\text { towards } \mathrm{Z}\end{array}$ & - & - & - & - & 0,762 \\
\hline$\varepsilon 1$ & 0,7 & - & - & 0,7 & - \\
\hline$\varepsilon 2$ & 0,238 & - & - & 0,238 & - \\
\hline
\end{tabular}

From these results, it can be seen there are the implications of each variable. First, it is regarding facility (X1) on customer satisfaction (Y). The findings of this research indicate that the facility has a positive and significant impact on customer loyalty in Borobudur Hotel in Jakarta. It can be seen from the acquisition of a beta value of 0,258 with probability $(\mathrm{Sig})=$ $(0,000)$. Second, it is the effect of service quality (X2) on customer satisfaction (Y). The objective research shows that service quality has a positive and significant impact on customer satisfaction in Borobudur Hotel in Jakarta. It is implied from the acquisition of a beta value of 0,400 with probability $(\mathrm{Sig})=(0,000)$. Third, it is customer satisfaction $(\mathrm{Y})$ on customer loyalty $(\mathrm{Z})$. It shows that customer satisfaction affects customer loyalty in Borobudur Hotel in Jakarta positively and significantly. The result shows the acquisition value of beta is 0,079 with a probability value $(\mathrm{Sig})=(0,013)$. Fourth, facility (X1) has an impact on customer loyalty $(Z)$. The findings indicate that the facility has a positive and significant impact on customer loyalty in Borobudur Hotel in Jakarta. The acquisition value of beta is 0,366 with a probability value $(\mathrm{Sig})=(0,000)$. Fifth, regarding service quality (X2) on customer loyalty $(Z)$, it indicates that the quality of the services has a positive and significant influence on customer loyalty in Borobudur Hotel in Jakarta. The acquisition of beta value is 0,641 with a probability value $(\mathrm{Sig})=$ $(0,000)$. 


\section{CONCLUSIONS}

Based on the result, the researchers can conclude it into several points. The facility has a significant and direct influence towards customer satisfaction in Borobudur Hotel in Jakarta. This shows that the poor facility will result in poor customer satisfaction. It means that better facility will also increase the customer satisfaction level. Moreover, service quality influences customer satisfaction in Borobudur Hotel in Jakarta directly and significantly. This shows that better service quality will increase the customer satisfaction level, while poor service quality will decrease customer satisfaction. Then, customer satisfaction also has a significant and direct influence towards customer loyalty in Borobudur Hotel in Jakarta. The higher the customer satisfaction is, the more loyal the customers will be. In contrast, when customers are not satisfied, it can be considered that they will not come back to the hotel again. In addition, the facility has a significant and direct effect on customer loyalty in Borobudur Hotel in Jakarta. If the hotel facility gets better than before, the customers will be more loyal. It can also be said that the poorer the facility is, the less loyal the customers will be. Similarly, service quality influences customer loyalty in Borobudur Hotel in Jakarta directly and significantly. The better service quality will increase customer loyalty. At the same time, if service quality is not good, the customers will not be loyal. Moreover, facility and service quality have a significant and direct influence towards customer satisfaction in Borobudur Hotel in Jakarta. This is indicated from when the facility and service quality are enhanced; the customer satisfaction will also increase. Vice versa, the poorer the facility and service quality are, the poorer customer satisfaction will be. Moreover, facility and service quality influence the customer loyalty in Borobudur Hotel in Jakarta. If the facility and service quality become better, the customer loyalty will increase. In other words, poor facility and service quality will make the customer loyalty decrease.

This research is expected to provide benefit by showing that it is important for the 21st-century hospitality industry to build the strategy to achieve the target. The strategy aims to be the provision of premium quality services to keep the customers satisfied and loyal to the organization, and subsequently to survive and compete in today's dynamic and competitive corporate environment effectively.

In addition to conclusions, this research provides suggestions for Borobudur Hotel in Jakarta. First, on the facility variable, from the questionnaire result on Borobudur Hotel in Jakarta, it is shown that the facility which consists of spatial planning, room planning, equipment, light and color setting in Borobudur Hotel in Jakarta is strongly related to the customer satisfaction. However, the result also shows that there is a weak correlation between facility and loyalty. It is found that one of facility dimensions that influenced loyalty is color. It is suggested that Borobudur Hotel in Jakarta to give new color nuance to the layout in the bedroom and to also keep the facility good, so the satisfaction and loyalty of the customers will not decrease. Second, the questionnaire result on customer satisfaction shows that the customer satisfaction including product quality, price, service quality and emotional factor have given satisfaction to the customer of Borobudur Hotel in Jakarta. However, there is a weak correlation between customer satisfaction and customer loyalty variables. The researchers suggest that Borobudur Hotel in Jakarta should increase the customer satisfaction to create customer loyalty. Third, for the customer loyalty variable, questionnaires indicate that customer loyalty consisting of repeat purchase, across product, and immunity does not have a significant influence as seen in SPSS result. There is a weak correlation between facility and customer satisfaction variables towards customer loyalty. Fourth, according to the questionnaire on service quality which consists of price and emotional factor shows that service quality dimension is the weakest influence towards customer satisfaction and customer loyalty. It is suggested that Borobudur Hotel in Jakarta pays more attention to the service quality, and give extra training to the employees to increase the service quality. Fifth, On customer loyalty variable according to the questionnaire result on Borobudur Hotel in Jakarta consisting of repeat purchase, refers other, across product, and immunity, it is shown that repeat purchase is the weakest. It is suggested that Borobudur Hotel in Jakarta should increase the service quality.

Furthermore, for researcher and reader, the researchers strongly hope that this research will be useful for the next research as a reference. This is also expected to help another researcher to understand the correlation between variables, and the path analysis method. Moreover, the reader can understand the dimensions in facility, service quality, customer satisfaction, and customer loyalty.

\section{REFERENCES}

Alaska, A. K., \& Supain, C. C. (2014). A study on the relationship between customer satisfaction and employee service delivery at Sutera Sanctuary Lodges's front office department at Kinabalu Park, Kundasang, Sabah, Malaysia. In SHS Web of Conferences (pp. 01079). EDP Sciences.

Alexander, H. B. (2015). “Booming” hotel di Indonesia terjadi kurun 2015-2018. Retrieved March 2016 from Properti.kompas.com/read/2015/02/08/200000921/. Booming.Hotel.di.Indonesia.Terjadi.Kurun.2015-2

Bou-Llusar, J. C., Camisón-Zornoza, C., \& Escrig-Tena, A. B. (2001). Measuring the relationship between firm perceived quality and customer satisfaction and its influence on purchase intentions. Total Quality Management, 12(6), 719-734.

Baker, D. M. A. (2014). The effects of terrorism on the travel and tourism industry. International Journal of Religious Tourism and Pilgrimage, 2(1), 58-67. 
Bucak, T. (2014). The effect of service quality on customer satisfaction: A research on hotel businesses. International Journal of Education and Research, 2(1), 1-12.

Ghozali, I. (2013). Aplikasi Analisis Multivariat dengan Program IBM SPSS 21 ( $7^{\text {th }}$ ed.). Semarang: Universitas Diponegoro.

Hana, O. D. (2014). Bisnis perhotelan: Pertumbuhan hotel di Indonesia terus meningkat. Retrieved April 5 $5^{\text {th }}$, 2016, from http://properti.bisnis.com/ $\mathrm{read} / 20140421 / 107 / 221127 /$ bisnis-perhotelan pertumbuhan-hotel-di-indonesia-terus-meningkat

Hikkerova, L. (2014) Loyalty programs : A study case in the hospitality industry. In IPAG Business School Working Paper.

Holjevac, I. A., Marković, S., \& Raspor, S. (2009, January). Customer satisfaction measurement in hotel industry: content analysis study. In 4th International Scientific Conference "Planning for the future learning from the past: Contemporary Developments in Tourism, Travel \& Hospitality".

Munir, K., \& Lodhi, S. (2015). How customer relationship marketing affect on customer loyalty and customer satisfaction: A case of Banking Sector Karachi, Pakistan. The International Journal of Business \& Management, 3(10), 586.

Neolaka, A. (2014). Metode penelitian dan statistik. Bandung: PT Remaja Rosdakarya.

Peric, V. (2005). Tourism and globalization. In Proceedings of the 6th International Conference of the Faculty of Management Koper (pp. 24-26). Slovenia.

Poku, K., Zakari, M., \& Soali, A. (2013). Impact of service quality on customer loyalty in the hotel industry: an empirical study from Ghana. International Review of Management and Business Research, 2(2), 600-609.

Priyatno, D. (2014). SPSS 22 pengolah data terpraktis. Yogyakarta: Andi Offset.

Sakhaei, F., Afshari, A., \& Esmaili, E. (2014). The impact of service quality on customer satisfaction in Internet banking. Journal of Mathematics and Computer Science, 9, 33-40.

Santoso, S. (2015). Pengaruh kualitas pelayanan terhadap loyalitas pelanggan laboratorium klinik populer Surabaya. Jurnal Ilmu \& Riset Manajemen, 2(6), $1-20$

Santoso, S. (2015). Statistik parametrik. Jakarta: PT. Elex Media Komputindo

Sekaran, U. (2013). Research methods for business: A skillbuilding approach $\left(6^{\text {th }}\right.$ ed.). West Sussex: Wiley

Soenarno, A. (2006). Front office management. Yogyakarta: Andi Offset.

Sofyan, I. L., Prdhanawati, A., \& Nugraha, H. S. (2013). Pengaruh fasilitas dan kualitas pelayanan terhadap loyalitas, melalui kepuasan konsumen sebagai variabel intervening pada Star Clean Car Wash Semarang. Diponegoro Journal of Social and Politic, 1(1), 1-12.

Sugiyono, P. D. (2012). Metode penelitian kuantitatif kualitatif dan $R \& D$. Bandung: Alfabeta.

Taylor, S. A., \& Baker, T. L. (1994). An assessment of the relationship between service quality and customer satisfaction in the formation of consumers' purchase intentions. Journal of retailing, 70(2), 163-178.

Vadehra, B. (2015). Indonesia Hotel Watch 2015. Retrieved from http://www.hospitalitynet.org/news/4071529. html 